\title{
$5 \quad$ Israeli Dead Sea cosmetics and charity for Palestinian children
}

\author{
Indonesian women's shopping \\ activities while on pilgrimage to \\ Jerusalem
}

Mirjam Lücking

\section{Introduction}

'Indonesians love to shop' - this is common wisdom among Palestinians and Israelis who work in the tourism sector in and around Jerusalem, and who evaluate their customers' preferences. In this regard, shopkeepers and tour guides consider Indonesians who travel to Jerusalem in guided religious package tours to be all the same - regardless of their religious affiliation. However, when it comes to the narratives that frame these shopping experiences, whether the customer is Muslim or Christian or to which affiliation in Islam and Christianity he or she - in most cases she - belongs, is relevant.

In his 'Theory of Shopping', Daniel Miller (1998) pinpoints a crucial similarity between shopping and ritual sacrifice. He argues that, in both cases, individuals construct social Others through material gifts. Thus, 'shopping is the construction of the other as the desiring subject' (Miller 1998, 148), fostering social relationships. In the example of Indonesians' experiences while on pilgrimage to Jerusalem, the social Other is not only the recipient of shopping items or a peer who reacts on new purchases - as in the example of Miller - but it is also the social Other behind the counter and the local population. Indonesians shop with the idea of engaging with Israeli and Palestinian Others. Furthermore, for Indonesian pilgrims shopping is also a form of accessing blessings, following a restorative and spiritual gain.

Thus, among Muslim and Christian Indonesian pilgrims, shopping is not only similar to ritual sacrifice, as argued by Miller, but, in fact, it constitutes part of the ritual process of pilgrimage performance. Leaving money at souvenir shops in the vicinity of holy places is a form of engagement with this place and charity is an integral part of journeys to Jerusalem. Indonesian Muslim pilgrims donate zakat and șadaqa alms to support Palestinians, and in every Christian service that is taking place during pilgrimage, the collection of money, which is usually donated to the hosting church, is crucial. 


\section{Mirjam Lücking}

Next to the idea of engaging with the holy place and with the local population, Indonesian pilgrims shop with thoughts about home: choosing gifts for relatives and friends and souvenirs that represent their completion of spiritual gains, which they achieve through the pilgrimage. In these layers of maintaining relationships and spirituality through shopping, there are ambivalences between the choice of products and the narratives that frame shopping activities, or in Miller's $(1998,66)$ words, a discrepancy between 'shopping practices' and 'shopping discourses'. In his analysis, Miller distinguishes discourse from ideology, the latter of which he sees as an inner conviction that is often not articulated in discourse. I relate to this analytical mapping and analyze the discrepancy between shopping activities and shopping discourses in contemporary pilgrimage from Indonesia to Jerusalem with a focus on women's agency. The seemingly contradictory title of this chapter reflects that the agency of the women involved is ambivalent, coming to the fore in the simultaneity of discourses about charity for Palestinian people and the actual purchases of Israeli products and luxury goods from international brands. I argue that the popularity of certain products relies on (1) their presumed function of cleansing and healing (especially in the case of Dead Sea cosmetics), (2) group dynamics within the 'travelling microcosm' of package tourism and (3) the agreement on commissions between travel agents, tourist guides and shopkeepers.

The ethnographic data stems from ongoing research on Muslim and Christian package tourism from Indonesia to Israel and the West Bank (Occupied Palestinian Territory ${ }^{1}$ ). Since December 2017, I accompany Indonesian travel groups in and around Jerusalem, speak with Indonesian pilgrims, clerics and tour leaders and interview Palestinian and Israeli tour guides, travel agents, shopkeepers and bus drivers. The research activities in Jerusalem were thus far complemented by two visits to Indonesia in July and August 2018 and August 2019, where I met Indonesian research participants in their home context. In addition, I relate to insights from previous research on Mecca returnees (see Lücking 2017, 2014). The chapter at hand foregrounds experiences of Muslim groups and relates to Christian groups in order to provide a comparative perspective and to tackle the history of Indonesians' pilgrimage to Jerusalem, which in fact started with Christian pilgrimage and only recently became popular in the Muslim tourism market in Indonesia.

\section{Pilgrimage tourism from Indonesia to Jerusalem}

Indonesia's Christian minority of 24 million people has been travelling in pilgrimage tours to Jerusalem since the 1980s. Some Christian research participants describe their Jerusalem pilgrimage as an equivalent to their Muslim compatriots' hajj to Mecca, which is a nation-wide highlight in celebrating Indonesians' presence at the holy sites, with pride of sending the largest national group of pilgrims to Mecca because of being the largest 
Muslim society in the world. However, recently, tour packages to Jerusalem have also started to boom in the Muslim tourism market in Indonesia. Travel agencies advertise pilgrimage to Jerusalem with reference to a hadith ${ }^{2}$ by al-Bukhari that mentions Al-Aqsa mosque in Jerusalem as a third pilgrimage destination, next to Mecca and Medina. Moreover, they promote the idea of supporting Palestine through tourism. 'After all, Jerusalem is a Muslim destination', an Indonesian Muslim travel agent stated (personal communication, 19 July 2018). Like him, many Muslim entrepreneurs in Indonesia who offer tours to the Middle East argue that visiting Jerusalem contributes to maintaining its Muslim character. With this argument, they compete not only with Christian Indonesians who see Jerusalem as a Christian destination, but even more so with fellow Muslims who demand that people abstain from visiting Jerusalem as long as it is under Israeli rule. Ideological competition and economic competition conflate in Indonesia's growing industry for Muslim tourism, which is also known as wisata halal (halal tourism).

In the wake of a boom in Mecca pilgrimage (Syarifah 2017; Feener 2004, 204), other destinations in the Middle East, such as Dubai, Istanbul, Cairo and Jerusalem, have become best-sellers (Lücking 2014). Waiting lists to participate in the hajj are long. ${ }^{3}$ Therefore, many Indonesian Muslims resort to undertaking the minor pilgrimage, the umra, and other religious travels. The number of documented Indonesian umra pilgrims jumped from approximately 500,000 in 2013 to more than one million participants per year since 2014 (The Jakarta Post 2017; Saudi Gazette 2017, 2018; Indopos 2018; Arab News 2019). In international comparison, Indonesia has a high female participation (approximately 50\%) in hajj departures (Bianchi 2004, 69), and even more so in umra and local pilgrimages. Robert Bianchi explains this by pointing to Indonesian women's presence in commerce, land ownership and their position in customary law in rural areas (Bianchi $2015,74) .{ }^{4}$ In almost all Indonesian pilgrimage groups that I have met between 2012 and 2019, I noticed a female majority.

Some package tours to the Middle East are advertised as umra-plus journeys (Lücking 2014, 137), combining the umra with visits of other destinations. ${ }^{5}$ Meanwhile there is also a wide range of Muslim tour packages to destinations all over the world that do not go via Mecca and Medina, as in the case of the Indonesians' pilgrimage to Jerusalem that usually go from Indonesia to Egypt, Israel, the West Bank and Jordan. Around 30,000 Indonesians visit Israel annually in guided package tours, despite the absence of diplomatic relations between Indonesia and Israel (Israeli Central Bureau of Statistics 2014, 2015, 2016; The Times of Israel 2019). The larger percentage (according to travel agencies, around $70 \%$ ) are Christian Indonesians. However, Muslim travel agents state that they aim to reverse this division, to show more Muslim presence in Jerusalem.

As a matter of fact, Muslim package tours to Jerusalem resemble the Christian 'Holy Land Tours'. However, while Muslim and Christian 
Indonesians' itineraries overlap, their travel narratives diverge. The idea of taking sides with the Palestinian people or with the Jewish people divides Indonesians along religious and denominational affiliations, in which the images of Palestinian and Jewish or Israeli Others are rather homogenising. As an example, many Indonesians assume that all Palestinians are Muslim and all Israelis are Jewish, while, in fact, the situation is much more complex (see Lücking 2019). However, when it comes to souvenir purchases, Indonesian women from all religious traditions appear to have similar tastes. Yet, even though they sometimes buy the exact same products, most prominently Israeli Dead Sea cosmetics, branded bags and jewellery, their expenditure, while on pilgrimage, is framed by polemics and differentiation from other religions or different affiliations within their own religion. Souvenir purchases as well as other financial transactions - like giving alms - are embedded in 'discourses of shopping' (cf. Miller 1998, 65). These discourses relate to globalized narratives of Islamophobia, Pan-Muslim solidarity and among new religious movements in Christianity - prosperity gospel and ideas of the Hebrew roots' movement. Therefore, I juxtapose practices and discourses and emic and etic perspectives in this context. As major shoppers and as a majority in the travel group, women take a vital role in both practice and discourse. A short episode that I observed when I accompanied an Indonesian pilgrimage group in Jerusalem illustrates this.

\section{Israeli Dead Sea cosmetics}

Tuesday, 3 April 2018: After three days in Jerusalem, a group of around 30 Indonesian Al-Aqsa pilgrims is on the way to Allenby Bridge, the border crossing between the West Bank and Jordan. Jerusalem was the highlight of their ten-day pilgrimage package tour, which the Indonesian travel agency advertised as a 'trip in the prophets' footsteps'. They started their journey in Egypt, visiting the pyramids, Mount Sinai and memorial sites ${ }^{6}$ for the prophets $\mathrm{Nabi}^{7}$ Harun, Nabi Saleh and Nabi Samiri. In Jerusalem they spent most of their time at al-Haram al-Sharif, the 'sanctuary', known also as 'Temple Mount', on which the Dome of the Rock and Al-Aqsa mosque are located. According to Islamic teachings, Al-Aqsa mosque is the third holiest place after the Holy Mosque with the Ka'ba in Mecca (al-Masjid al-Harām) and the Prophet's Mosque in Medina (al-Masjid al-Nabawī), and according to a hadith from al-Bukhari, the prophet Muhammad commanded his followers to pilgrimage to these three mosques. Besides Al-Aqsa, the tomb of Nabi Ibrahim in Hebron and a memorial site for Nabi Musa were part of the group's pilgrimage or ziyāra. Their journey continues in Jordan, with visits to memorial tombs of Nabi Shu'aib, Nabi Yosa and Nabi Ayub. Moreover, they will explore the Dead Sea and the archaeological sites in Petra, in Southern Jordan, before flying back to Jakarta.

I am sitting next to Indah, ${ }^{8}$ a young woman from Surabaya, who tells me that she decided to go on the pilgrimage with other women of her Qur'an 
reading/prayer group (kelompok pengajian). She had been to Mecca twice for the minor pilgrimage, umra, with the same group and now she wanted to complete her pilgrimage duties by visiting Al-Aqsa. Our conversation is interrupted as the tour guide makes an announcement into the coach's microphone:

Ladies and gentlemen, this is the end of your visit to Palestine, we are on our way to the border. I hope that your pilgrimage to Al-Aqsa was full of blessings and wish you a smooth onward journey. When you leave Palestine, of course you can keep your money in your pockets and spend it in Jordan. But, if you wish, you have the chance to do something good for Palestinian children. Before we arrive at the border, we have one final stop. We will visit Jericho, the oldest city on earth and the centre for the production of high-quality Medjool dates. Ladies and gentlemen, in Jericho we still have time to visit two shops, where you have the opportunity to buy Medjool dates and Dead Sea cosmetics. The Dead Sea minerals in these cosmetics cure all skin diseases, clarify, brighten and nourish the skin, rejuvenating it. Again, you can keep your money and take it to Jordan, but if you buy here, you support the local Palestinian community in Jericho.

In Jericho the shopkeepers in the Dead Sea cosmetics store welcome the group with Indonesian greetings and invite us to see a demonstration of a mineral mud face mask. As a German anthropologist, I'm identified as an exotic group member, and I'm asked to be a volunteer to test the mud mask. In front of the curious eyes of the female group members, Rashid, who works in the shop, spreads the Dead Sea mud mask on my arm, explaining in Bahasa Indonesia how the mud purifies and brightens the skin. In order to prove that the mask contains minerals, he uses a magnet to remove it. $\mathrm{He}$ places the small magnet under a tissue and with one wipe the mud 'magically' flies off my arm into the tissue. The women cheer in surprise. Rashid smiles and continues his explanation:

If you are interested in this product you can buy our special offer package with the mud mask, day and night moisturizers and age-control eye cream, normally 250 dollars, today with a special discount for Indonesian Muslim groups: 170 dollars.

While the women enthusiastically begin to enquire about the other products in the package and discuss prices and discounts with Rashid, the men wait in front of the shop, smoking and drinking Arabic coffee. Some of them joke that their wives make them poor, others later join their wives in choosing cosmetics and small souvenirs that are also available for sale in the shop. Indah, who is not married, discusses what to buy with other female members of her Qur'an reading group while I talk to Rashid, who 
tells me that Indonesians always want to buy the same products. If one person buys the mud mask - one of the most expensive products in the shop the others will do the same.

\section{Ambivalent agency}

This episode in the Dead Sea cosmetics shop in Jericho reveals ambivalences in shopping activities. Coming back to Miller's argument that people shop with thoughts about social Others, it seems to be obvious that Indonesian women shop with caution of what Others will think about their purchases. According to reports of shopkeepers, they usually buy similar products, which affirms these products' value and a feeling of belonging to the group. Moreover, they think about social relationships back home in Indonesia, choosing souvenirs for friends and relatives and gifts for colleagues and neighbours. This does not only correspond with Miller's analysis of shopping in general but even more so with findings on souvenir purchases in tourism. ${ }^{9}$ However, the social Others are also those who research participants imagine as 'poor Palestinians', prominently represented through the image of Palestinian children and Indonesian women's motherly empathy. With this idea of Palestinian Others, an elderly female Indonesian pilgrim argued:

Even though the prices here are higher than in Jordan or Egypt, we have to buy stuff. In order to support the people here, apart from giving them food and money, we have to shop. To shop and to shop - no matter what the price is, we will buy it.

(personal communication, 3 April 2018)

She considered shopping to be an act of solidarity and reported that she and her husband had spent USD 3,000 on șadaqa (voluntarily giving alms) and shopping during their visit to Jerusalem. The amount of money the women spend ranges significantly. However, most of the pilgrims come from the urban middle classes and many even from the upper classes, who spend substantial sums of money (USD 1,000 up to 10,000, according to travel agencies and pilgrims) on jewellery and other luxury goods. The moralizing discourse of supporting the Palestinian economy legitimizes the purchases, including purchases of expensive luxury goods.

In his analysis of American Christian pilgrims' purchases of massproduced souvenirs in commercial souvenir shops in Israel, Jackie Feldman $(2015,288)$ describes souvenirs as 'vehicles of religious and moral values'. He further shows how religious discourse and ritualized behaviour construct the meanings of souvenirs as signs of communitas. Like these Americans, Indonesian pilgrims make their shopping experiences meaningful through moralizing discourses and communal religious practices. However, it turns out that the practical dimension of shopping and its socio-cultural meanings often contradict the narrative dimension. The narratives relate 
to solidarity with social Others in Palestine and Israel, marking differences in religious affiliation and political standpoints, while the shopping practices and preferences reveal commonalities among all Indonesians. Both discourse and practice - constitute women's agency as major shoppers.

Through this agency social norms are enforced and redefined. In many cases, the way Indonesian women shop equals domestic pilgrimage shopping. Next to pilgrimage travels to Mecca and Jerusalem, which are respectively obligatory and recommended, a much higher number of Indonesians goes on local pilgrimages, or more precisely ziyarra, to the tombs of local Muslim saints, Javanese kings and famous politicians and religious leaders. While these forms of pilgrimage are rooted in Indonesian history, they are recently booming anew (see Quinn 2019; 2008; Slama 2014). Martin Slama (2014) shows that their commercialization is encouraged by the state and private actors who promote wisata religi (religious tourism) and expand it beyond the well-known tombs of the wali songo (nine saints) in Java to the wali pitu (seven saints) in Bali, whose graves were restored and marketed only recently. Today, wisata halal has become the new best-selling segment in tourism. Thus, commercialization and shopping activities are widespread in all forms of Indonesians' religious travels in and beyond Indonesia, or as George Quinn $(2008,64)$ puts it, 'money and pilgrimage go together'. Quinn shows that the commercial transactions while on pilgrimage are metaphorical actions that 'parallel devotional ritual and illuminate the relationship between believer and God' (Quinn 2008, 64). In the case of pilgrimage to the graves of local saints, donations and offerings are seen as a way of creating a relationship with the saint who acts as intercessor between pilgrim and God, and souvenir purchases are seen as supporting the local population as well as the pilgrims' spiritual aims (Quinn 2008, 67-70). Quinn further explains that pilgrims consider these spiritual aims in monetary exchange as a contract with God (Quinn 2008, 74), which corresponds with widespread understandings of zakat and șadaqa charity as being linked to the idea of securing one's place in paradise and acting upon Qur'anic commands (see also Bruijn and van Dijk 2009).

Thus, on the one hand, Indonesian women create a continuity with domestic practices, while on the other hand, their shopping activities in Jerusalem are politicized and mark demarcations from other Indonesians. The 'ambivalent agency' does not only concern the shopping discourses and practices abroad but also their meaning in the local context. In order to demonstrate how this works, in the following I give examples of continuity in shopping practices and frictions through politicized narratives and representations of social class.

\section{New Muslim lifestyles and cultural continuities}

A closer look at shopping practices reveals similarities among all Indonesian tourists. Tourist guides and participants jokingly state that Indonesian women are famous as 'tukang belanja' (literally 'shopping artisans'). 
A Jakarta-based travel agent for halal tourism explained that women were her main customers, many of whom were widows or early pensioners whose husbands cannot take time off from work. Research participants explained the central role of women in Muslim pilgrimage in a pragmatic manner, the argument being that religious reasons enable women to leave their houses and travel. The women's independent travels mark a continuity of Indonesian women's engagement in neighbourhood associations, alumni unions and charity organizations - activities in which Indonesian women play active roles and that are seen as legitimate leisure activities.

Like Indah, many pilgrims that I met in Jerusalem are part of a group that meets for religious and charitable activities. Besides pengajian (Qur'an study), they sometimes join savings unions (arisan), where members meet routinely, putting money together and alternately receiving the sum of all savings. Furthermore, they recounted that they would often go on trips together (jalan jalan), especially to visit religious sites (ziyāra) but also to reunite with friends (silaturahmi). During my visits to Indonesia in 2018 and 2019, I was able to join such reunion meetings. Interestingly, the activities resembled those that had characterized the Al-Aqsa pilgrimage. Besides praying together and eating together, the women filled the time with taking pictures and shopping. The same holds true for Christian pilgrims. Shopping for religious souvenirs was obviously not only important while on pilgrimage to Jerusalem but also during reunion meetings in Indonesia.

Women constitute the majority in travel groups and some groups consist of women only. Also if there are male participants, it is the women who make the financial transactions. This is another continuity of local norms. In Javanese gender roles women have an influential connection to money (see Brenner 1995). Financial elements in community meetings and leisure activities have historically been dominated by women (see Hospes 1992), which some Indonesians explain with the belief that money is impure. Suzanne Brenner (1995) offers a thought-provoking critique on this, revealing that from women's own perspectives, women are more gifted in controlling their nafsu (desires and passions) and are therefore better suited to administer finances and at the same time deal with spirituality. Men, who are officially responsible for the spiritual integrity of the family in the Javanese belief system, do not handle money openly (see Wolf 1990). Brenner $(1995,41)$ gives voice to women who express 'the opinion that most men have uncontrollable passions and childlike dispositions which prevent them from acting in the best interests of their families'. Among Indonesian women whom I met in Jerusalem and who belong to urban middle classes, there were many entrepreneurs who make money from small online retail businesses: for example selling clothes, food and cosmetics via social media. This means that their travel and shopping activities are not just a legitimate 'housewife activity' but that women deal with significant amounts of money in this context, often having the say of what money is spent on and making their own money. During travel, women often physically carry 
money in their purses and spend it on donations and shopping. Like in the scene described above, male participants sometimes take a break while women explore shops, choosing souvenirs and only consulting their husbands before making their final shopping decisions.

Thus, today as in the past, Indonesian women are engaged in business and the administration of family finances. Women's agency in new spheres of halal business emerges from this continuity and shapes public religious cultures in Indonesia. While being rooted in continuity in terms of gender roles, women's activities also represent something new: pious economic success and modernity. Expensive accessories and fashionable clothing mark the social status of female Muslim entrepreneurs and consumers.

Travel agencies relate to women's role in shopping activities, as can be seen by one of the Muslim agencies' adverts for cosmetics shops displaying the statement: 'Dead Sea mud has its own benefits for women, functioning as a skin smoothing scrub' (Cheria Holiday 2018). ${ }^{10}$ A clear and bright skin is a beauty ideal in Indonesia, as can be seen in the omnipresence of white skin colour in cosmetics advertisements in Indonesia (Yulianto 2007). Among Indonesians, Dead Sea cosmetics are promoted through claims of the cosmetics' brightening function, which is popular among Christian and Muslim women alike. Furthermore, substances that are considered to carry curing and miraculous qualities are generally popular among Indonesians, and shopkeepers and tourist guides know how to promote this - in Bahasa Indonesia and often in a humoristic manner. In a similar vein, Indonesians love objects that are deemed to be powerful, like expensive jewellery with special stones. This is similar to domestic searches for magical objects and consultation with paranormal practitioners and healers (see Schlehe 2012). What makes all these shopping items special is the fact that they were bought in the Holy Land or the 'Land of the Prophets'. Even if they are mass-produced souvenirs made in China, the proximity to the Holy Place makes them special. ${ }^{11}$

When measuring the time of pilgrims' activities, it turns out that pilgrims spend almost as much time in shops as they spend in churches or mosques. Pilgrims, guides and priests sometimes take a self-critical stance on this, referring to the allure of shopping as pencobaan (temptation), or joking that the participants' suitcases get children (koper beranak) because they buy so many souvenirs that they have to buy additional bags and suitcases. However, in interviews pilgrims also argue that shopping is not a hedonistic activity. They choose items that remind them of spiritual renewal and purchase souvenirs because they are thinking of relatives, colleagues and friends back home. Some of them also identify social pressure to bring lots of oleh-oleh (gifts) home to Indonesia. Thus, the shopping activities are characterized by a simultaneity of cultural continuity and new Muslim lifestyles among Indonesian women. The following analytical differentiation of shopping items suggests that small gifts and souvenirs mark cultural continuity, while luxury goods represent modern Muslim lifestyles. 


\section{Communal gifts, souvenirs and luxury goods}

Based on the categorization of my Indonesian interlocutors and my own observations when accompanying them, three different types of shopping items reveal how shopping marks continuities and frictions: (1) (religious) souvenirs, (2) gifts and (3) luxury goods. In Bahasa Indonesia and in emic conceptions there is a differentiation between kenang-kenangan (souvenirs) and oleh-oleh (gifts). For the items that I label as luxury goods here, there is no specific Indonesian vernacular term. As I mentioned above, souvenirs and gifts are also important in domestic travels in Indonesia. In these domestic travels, oleh-oleh often consist of culinary gifts (Quinn 2008, 71; $2019,66)$. In every region in Indonesia there is a local speciality which serves as oleh-oleh and which can be purchased in oleh-oleh stores near tourist attractions, pilgrimage sites, train stations and airports. Frequently, Indonesians carry cardboard boxes from one city to another in order to share something from their travel experience.

While on pilgrimage to Jerusalem, many Indonesians purchase dates as oleh-oleh. The best dates in the region are said to be the Medjool Dates from Jericho. As dates are also a very typical oleh-oleh from Mecca and Medina, some Christian research participants shared their reflection that after their visit to Israel and Palestine they realized that dates were not a specifically Muslim speciality but a Middle Eastern one. An elderly Catholic woman from Central Java recounted that she had liked dates so much that she went looking for them once back in Indonesia. Her search for dates eventually led her to Muslim shops that she had never visited before. Other oleh-oleh are key chains, magnets, t-shirts, shawls, bags, hats and pens with slogans like 'I love Jerusalem' or Palestinian, Israeli, Muslim, Jewish or Christian symbols. Many of these small gifts are sold by flying vendors who wait for tourists in front of religious sites and parking lots. This means that there is not a lot of time to choose the gifts. Pilgrims buy them hastily on the way to the bus or entering the site they are visiting. While oleholeh are more or less the same for Muslim and Christian pilgrims, and in the case of the dates even inspire a cross-religious experience in the home context back in Indonesia, the choice of kenang-kenangan marks different religious affiliations.

Kenang-kenangan souvenirs are usually bought for personal use and for close friends and family members. Choosing the right souvenir takes much more time than choosing oleh-oleh. Travel groups spend around one hour in large, air-conditioned souvenir shops, sometimes more. Religious paraphernalia and local religious artworks are popular personal souvenirs. Examples of this include rosaries and Muslim prayer chains, olive wood carvings, holy water from the Jordan River, wedding wine from Canaan, oils and candles, icons and statues. Evangelical and Pentecostal Christian pilgrims have a liking for Jewish paraphernalia, like menorah and Chanukah candelabras, shofar horns and tallit prayer shawls, which are less 
popular among Catholics or Lutheran and Calvinist Indonesian Christians. ${ }^{12}$ For Muslim groups, pictures of Al-Aqsa mosque and the Dome of the Rock are highly popular. Moreover, they like souvenirs with the Palestinian national colours, like shawls, and the black-white chequered kuffiyya head dress. Some of these items are thought to contain baraka (blessings), and one of my Muslim research participants joked that a prayer chain from a holy place could become a jimat, a magic tool. That Indonesians consider souvenirs as vessels for blessings is another similarity with local pilgrimage in Java. Rizal Abdi $(2017,10)$ explains that pilgrims consider shopping to be a manifestation of baraka from the saints of God. Similarly, Quinn (2008, 75 ) shows that pilgrims invest in pilgrimage as a source of blessings, supernatural power and success. These hopes for good fortune and success are most evident in pilgrimage travels of Indonesian politicians. Both among Muslim and Christian groups, I met Indonesian politicians who saw their pilgrimage as a preparation for election campaigns and sought blessings and prayers for success. Therefore, even though the kenang-kenangan do mark different religious affiliations at first sight, the belief in blessings and magical means is yet another shared characteristic of Muslim and Christian souvenir purchases.

The quality of being filled with blessings depends not only on what the item is but also where it was bought. Christian pilgrims usually shop in souvenir shops in Bethlehem, Nazareth, at the Jordan River baptism site Yardenit or in church-run shops at pilgrimage destinations like the Garden Tomb (which is popular among Protestant Indonesians) or the Church of St. Peter in Gallicantu (with one of the favourite shops among Catholic Indonesians), while Muslim groups mostly shop in Jericho and Hebron. In pilgrims' and guides' discourses about shopping, the meaning of these places refers to biblical/Qur'anic and political significance. Interestingly, not only vendors compete but so do pilgrims by considering who has higher quality, purer and more authentic and powerful souvenirs.

Some of these religious items, especially small ones like rosaries, are also common as oleh-oleh for friends and relatives back home. Some pilgrims buy dozens of rosaries and prayer chains, saying that distributing them in prayer groups will help to strengthen their friends' faith and bring them closer to the blessings of the Holy Land. Again, even though these souvenirs appear to highlight the different religious affiliations, they also ultimately reveal commonalities in missionary activities.

The third category of shopping items - luxury consumer goods - includes the above-mentioned Dead Sea cosmetics. Different from oleh-oleh and kenang-kenangan, these luxury goods do not mark cultural continuity but rather new trends in Muslim lifestyles. Besides cosmetics, jewellery, perfume and branded handbags are popular luxury goods among Indonesian pilgrims - especially among female pilgrims from the upper middle classes. Here, shopping activities are connected to class affiliation - or aspired class affiliation - of the pilgrims, as mentioned above regarding the representation 


\section{Mirjam Lücking}

of modernity and success. Some pilgrims are rich and highly interested in expensive luxury goods. Others do not have the same economic resources, but they might still buy luxury goods, using money that they saved for the trip. Literature on Indonesia's new middle classes indicates that the amount of money spent does not necessarily allow a conclusion of a person's economic affluence. In many cases, the purchase of consumer goods represents the longing to be part of the middle class rather than the actual economic situation of a person (see Berenschot and van Klinken 2014). Thus, souvenirs are not only a personal reminder of having completed the journey but also physical proof of pilgrims' social status - especially in the case of prestigious pilgrimage journeys and high-priced consumer goods (Abdi $2017,9)$. The practical act of purchasing something from the holy site contributes to the realization of having been there. One Indonesian tour leader explained to me, 'if we haven't bought anything, it's like we haven't been here' (personal communication, 3 April 2018). Regarding the discourses that frame these shopping experiences, many pilgrims were proud of 'having left' lots of money 'in the Holy Land' or 'in Palestine'.

\section{Framing shopping experiences}

In order to make the shopping experience meaningful and legitimate, the right discursive framing is important. Guides and shopkeepers know about Indonesian tourists' tastes. They are experts in their business and like Rashid, the shop keeper in the Dead Sea cosmetics store, they report that all Indonesian groups share some similar shopping practices, such as buying the same products and brands, wanting discounts or looking for stories about the souvenirs. Many shops invite pilgrims to listen to their promotions in Indonesian language, including jokes and quizzes. This interest in humoristic, entertaining shopping experiences and Indonesians' humorous self-reflections are another element that reveals practical commonalities among Muslim and Christian Indonesians, even though the narratives suggest divisions. Interestingly, shopkeepers are talented in using the 'right' narrative for different target groups. One of the staff members in a big Bethlehem souvenir shop joked that products sold better when accompanied by a story. If he advertised body oil as 'the oil of Mary' or the 'oil of St. Anna' it sold much better, and even more so if he claimed that it has a curing function. So, Israelis and Palestinians who work in the tourism sector saw less differences between Christian and Muslim Indonesians than commonalities in their taste and the way they want to shop.

The predominantly male Palestinian vendors know how to create a comfortable atmosphere in which pilgrims enjoy their shopping experiences and feel that it supports their ideological and religious sentiments. Rashid labelled the discount for the Dead Sea cosmetics package as a special price for 'Muslim groups', stressing solidarity as Muslim brothers and sisters. However, this framing is exchangeable with other narratives, as I realized 
when I came back to the same shop with a Christian group. Shopkeepers are professional in adjusting their promotions, relating to pilgrims' emotions. Some of them impressed Indonesian Christian groups with their knowledge of domestic Indonesian politics, telling a Catholic group that they would pray for Ahok - the former governor of Jakarta who is a member of the Chinese Christian minority and who was imprisoned because of accusations of blasphemy. However, my observations reveal that which shops are visited does not so much depend on religious affiliation but more on connections between shop owners, travel agents and guides who agree on commissions.

While Palestinian and Israeli shopkeepers are flexible in adjusting their narratives, the mostly female customers with whom they interact find it important to feel reassured in buying in the 'right' shops. This is especially clear among Muslim pilgrims who wish to boycott Israel and show their solidarity with Palestine. These nuances reveal that besides boundaries between Muslim and Christian Indonesians, there are also intra-Muslim and intra-Christian tensions. For Christians, this emerges especially in the divide between new religious movements, like Pentecostalism, and the large mainline churches (see Hoon 2018). Among Indonesian Muslims, there is controversy regarding the appropriate position to take towards the Israeli occupation of Palestinian territory. In 2012 Sheikh Yusuf al-Qaradawi, one of the world's leading Muslim preachers (from the Muslim Brotherhood), issued a fatwa (legal opinion) against non-Israeli or non-Palestinian Muslims visiting Jerusalem. However, Palestinian authorities and travel agencies argue that visiting Al-Aqsa contributes to securing its status as a Muslim pilgrimage site. They argue that showing this Muslim presence is particularly important as more and more Jews try to enter the Al-Aqsa complex to pray there, which in fact conflicts with the Israeli law that forbids Jews from visiting it. Muslim Indonesians explained that through their visits they want to safeguard the Muslim character of the site. When Indonesian participants doubt if their visit really supports Palestine, because from their point of view visiting the region means indirectly financing the current Israeli government and its oppression of Palestinians, through payments for visas, hotel taxes and exit taxes, travel agents advise them to balance this through giving alms and doing 'solidarity shopping'. Concerning this example, the intra-Muslim controversy about visits to Jerusalem inspires what I call 'narratives of separation' (Lücking 2019): narratives, images and discourses that draw on dichotomous categories of Self and Other and promote ideas of bipolarity and of competing sides. In the vein of legitimizing the travel to Jerusalem, Indonesian travel agents outperform their critics by saying that their visits to Jerusalem support the Palestinians through their presence as Muslim brothers and sisters, through shopping and alms giving. In order to underline their pro-Palestinian intention, the narrative sometimes becomes anti-Israeli and anti-Jewish, and in some cases also anti-Christian, suggesting a global divide between those who are perceived as 'threatening Islam' 


\section{Mirjam Lücking}

and Muslim brothers and sisters. It does not come as a surprise that some travel agencies promote demonstrations of the Aksi Bela Islam movement (Islam Defence Action) in Jakarta among their customers, giving discounts to those who join the demonstrations.

These discourses create the impression of oppositional blocks. However, considering the underlying intra-Muslim tensions and Indonesian pilgrims' self-reflection about commonalities, on a practical level it seems that while the tourism industry and shopping experiences are arenas in which to engage in boundary-making, they can also inspire reflection and togetherness.

\section{Mobility and reflection}

Dead Sea cosmetics are the most vivid example of the contradictory nature of homogenising shopping discourses - in spite of similarities in taste and shopping practices. Even though many Indonesian Muslim pilgrims claim that they want to boycott Israel, and tourist guides as well as participants stress the importance of staying in hotels in East Jerusalem and buying from Palestinian shops, when it comes to Dead Sea cosmetics and other luxury goods, there is little interest in knowing where the products come from. The only difference between Muslim and Christian groups is that Christian groups mostly buy these cosmetics in souvenir shops in Qumran, next to the Qumran scrolls archaeological site, where the shops are run by Israelis, while Muslim groups buy in the Palestinian shops in Jericho. However, all Dead Sea products come from Israeli companies and are in fact highly controversial regarding the political implications of their production in occupied West Bank territory and the environmental damage that the cosmetics industry is causing in the Dead Sea area (see The Jerusalem Post 2011). Obviously, Indonesian customers are unaware of these controversies and of the shopkeepers' positions on questions of boycotting.

When I asked Rashid - and other shopkeepers - about this, he told me that he, as a Palestinian who works in tourism, does not agree with a complete boycott of Israeli products. He differentiated between products from settlements - like Ahava, the most famous Israeli Dead Sea cosmetics brand - and those that have their factories within the internationally recognized borders of Israeli territory, like Premier. Rashid was happy that, under the pressure of boycott of settlement products, Ahava had in fact moved out of the West Bank, which would mean that soon he would start to sell Ahava products, which have a well-established reputation among Indonesian tourists.

The female pilgrim Indah was surprised when she heard me and Rashid talking about Dead Sea cosmetics' production in Jewish settlements in the West Bank, not really knowing what a settlement is and expressing her confusion about our talk on the differences between products from settlements and others - she had not known at all that the products come from Israeli companies. Apparently, for package tour pilgrims like Indah, the 'microcosm' or what Cohen (1972) calls an 'environmental bubble' 
of the group experience of praying, shopping and travelling together and engaging in the 'right' narrative weighs more than actual engagement in political questions on the ground. The pilgrims emotionally relate to the Palestinian cause and consider their shopping as being an act of charity, yet their knowledge about the highly complex political situation is restricted to stereotypical ideas of suffering Palestinian children, whom they see in the advertisements of charity organizations in Indonesia and whom they deem would profit from 'solidarity shopping'. Interestingly, the more expensive the products are, the less important their actual origin appears to be, which hints at the fact that in this case, the reaction of social Others at home appears to be more important than knowledge about the social Others in the pilgrimage destination. This is true for luxury goods like Dead Sea cosmetics, and even more so for diamonds from the national Israeli diamond manufacturer Caprice Diamonds, which are prestigious souvenirs that show the social status of a pilgrim.

Indonesian women shop with the idea of clearly identifiable, homogenous, opposed camps - Jewish Israel and Muslim Palestine. To a certain extent, their travels raise awareness of the complexities and in some cases even cross-religious experiences. However, their relations to various social Others in this context appear to be more relevant for the local Indonesian context than the Middle Eastern one. Shopping discourses relate to ideas of the Israel-Palestine conflict, while shopping practices connect to social relationships back home in Indonesia and within the travel group.

\section{Conclusion}

The discrepancy between shopping discourses and shopping practices corresponds with general patterns of shopping and souvenir purchases, as described by Feldman (2015) and Miller (1998) for Western contexts. Different from the Western contexts, the example at hand and observations from domestic pilgrimages, made by Slama (2014) and Quinn (2008) show that the Indonesian shopping preferences and souvenir exchanges are grounded in local customs and historical social structures, in which Indonesians relate to several social Others and to the spiritual dimension of seeing souvenirs as means of connecting to God and accessing the power of blessings. Furthermore, women maintain their say over money (Brenner 1995) and through their purchase decisions actively engage in the construction of social realities.

Shopping might appear like a merely entertaining activity. However, my observations allow the conclusion that Indonesian women exert meaningful agency through shopping activities on their pilgrimage to Jerusalem. Their agency defines the continuity of certain norms, like gender roles and social obligations as well as the access to baraka as presented through the differentiation between oleh-oleh and kenang-kenangan. Through the purchases of other shopping items, like luxury goods and framing discourses, new norms of what it means in today's Indonesia to be a 'modern Muslim 
woman' are introduced. Indonesian women like to shop in groups and often buy similar products, they love entertaining promotions of products and stories of healing, blessings and Asian beauty ideals, which makes Dead Sea cosmetics so popular among Indonesian women. In this regard their transactions relate to ideas of modernity as well as restorative and spiritual aims, which are rooted in historical experience.

Indonesian women's agency in shopping activities is thus ambivalent on the transnational and local Indonesian levels. It has an impact on the Indonesian social reality and on tourist spaces abroad. Yet, in spite of discourses that suggest frictions, the data reveal that practical shopping activities of Indonesians of different religious affiliation share numerous common elements, thus pointing to cultural continuity and unity, which is apparently particularly crucial when travelling abroad. Apparently, these commonalities among Muslim and Christian Indonesians are more evident from an outsiders' perspective - like that of the German anthropologist or the Palestinian shopkeeper - even if the experiences of mobility enhance self-reflection in some cases, as the humoristic statements show.

Miller differentiates ideology, as being implicit, from discourse, being explicit. Thus, in the analytical categories of Miller, Indonesian women's discourses relate to globalized issues of Muslim solidarity, Islamophobia and the Israel-Palestine conflict. Apparently increasing commercialization and competition in the field of religious tourism foster these discourses and new Muslim lifestyles, as can be seen in travel agencies' marketing narratives. Yet the underlying ideology, which is often not verbally articulated and inspires shopping practices, is deeply ingrained in historically grown Indonesian - and in many cases Javanese - conceptions of the world and contemporary middle-class lifestyles. The discourses appear to divide Muslim and Christian Indonesians of different denominational affiliations and members of different social classes, while the ideologies 'which remain implicit in practice' (Miller 1998, 72), unite Indonesians in their preference for magic items, collectivism in souvenir purchases, beauty ideals, humour and gender roles. During pilgrimage to Jerusalem, Indonesian participants see the area through the lens of holy scriptures, through the lenses of their smartphone cameras and with a homeward perspective - thinking of social Others at home and their relation to God. This is reflected in their approach to shopping. Ideas of charity and of political solidarity remain on the surface and function within the competition with other groups, including other groups within one's own religious tradition, in Indonesia. Thus, the contradiction between shopping practices and shopping discourses shows that Indonesian women's agency lastly relates more to the Indonesian domestic context rather than to the Middle Eastern one.

\section{Acknowledgements}

For their openness to research activities, I thank numerous travel agents, tour guides, shopkeepers and pilgrims who remain anonymous in this 
publication. Nuki Mayasari and Ibu Lestari Heru made me aware of important perspectives on shopping in the domestic Indonesian context my thanks to them stand also for many other colleagues and friends in Indonesia who keenly engage with my research topic. Furthermore, I am very grateful to Martin Slama who provided valuable feedback on an earlier version of this chapter and to the participants of the Social Anthropology colloquium at the University of Konstanz who likewise engaged with the text in a critical and constructive manner. Work on this book chapter was facilitated through a postdoctoral fellowship at the Hebrew University of Jerusalem and the Center for the Study of Conversion and Interreligious Encounters at Ben Gurion University of the Negev, funded by the Israel Science Foundation under grant number 12/1754. In Beer Sheva, I especially thank Jackie Feldman for our thought-provoking conversations. At the Hebrew University, I sincerely thank Ronit Ricci who created an inspiring environment for Indonesian studies. Furthermore, I thank the students who joined my class on Islam in Southeast Asia and who enriched the discussion about religion and commercialization through their own perspectives from the Palestinian and Israeli societies. The finalization of the text and follow-up research are enabled through an ongoing postdoctoral fellowship at the Martin Buber Society of Fellows in Jerusalem, sponsored by the German Federal Ministry of Education and Research.

\section{Notes}

1 With reference to the common terminology and legal definition of the United Nations, the International Court of Justice and the European Union, the Palestinian territories that have been under Israeli occupation since 1967, namely the West Bank (including East Jerusalem) and the Gaza Strip, are defined as Occupied Palestinian Territory.

2 A hadith is a transmission or report about the teachings of the Prophet Mohammad. Sahih al-Bukhari is one of the most well-known authors of canonical hadith collections.

3 The Saudi Arabian administration regulates the number of hajj pilgrims from all over the world, and Indonesia is currently allocated a quota of around 200,000 participants per year (Indonesian Ministry of Religious Affairs 2013, 2016).

4 Technically, the female majority in hajj and umra pilgrimage is enabled through an alternative muhrim system in Indonesia (Salaam Gateway 2017). Single female travellers to Mecca who are aged under 45 need to be accompanied by a male family member. According to the news agency Salaam Gateway (2017), Indonesia has a special agreement with Saudi Arabia allowing Indonesia's female pilgrims without male guardians (mahram) to be placed in a convoy with other single females and act as each other's mahram.

5 For similar trends in Malaysia see Thimm 2018.

6 These memorial sites for the prophets of Islam (many of whom are also known as patriarchs or prophets in Judaism and Christianity) look like grave sites and are referred to as maqām (Arabic for grave/tomb). However, as there is no proof of actual burial sites, they are not considered as the actual tombs but as memorial sites. 


\section{Mirjam Lücking}

7 The Arabic term 'nabi' means 'prophet'.

8 All names are pseudonyms.

9 For more general studies on souvenir purchases in religious travels see Gordon 1986 and Hitchcock 2000.

10 'Lumpur di laut mati mempunyai khasiat tersendiri bagi kaum wanita yaitu berfungsi sebagai lulur penghalus kulit' (Cheria Holiday 2018).

11 Among some Christian pilgrims it is common that the priest or minister blesses all souvenirs (for similarities with Russian Orthodox pilgrims; see Feldman 2015, 298).

12 Menorah, shofar and tallit are Jewish paraphernalia. A menorah is a sevenarmed chandelier, which is a symbol of Judaism and of the state of Israel. The shofar is a horn that is blown during religious ceremonies, most famously on the Jewish New Year, Rosh Hashana. Tallit is usually a white piece of cloth with fringes that is used to cover the body during prayer.

\section{References}

Abdi, Rizal. 2017. 'Flock with God, Ally with Money.' Nizham: Jurnal Studi Keislaman 5 (2): 1-14.

Arab News. 2019. 'Saudi Arabia Issues more than 4.1 Million Umrah Visas.' February 25, 2019. http://www.arabnews.com/node/1457471/saudi-arabia.

Berenschot, Ward and Gerry van Klinken, eds. 2014. In Search of Middle Indonesia: Middle Classes in Provincial Towns. Leiden/Boston, MA: Brill.

Bianchi, Robert. 2015. 'The Hajj and Politics in Contemporary Turkey and Indonesia.' In Haji: Global Interactions through Pilgrimage, edited by Luitgard Mols and Marjo Buitelaar, 65-84. Leiden: Sidestone Press.

2004. Guests of God: Pilgrimage and Politics in the Islamic world. New York: Oxford University Press.

Brenner, Suzanne. 1995. 'Why Women Rule the Roost: Rethinking Javanese Ideologies of Gender and Self-Control.' In Bewitching Women, Pious Men: Gender and Body Politics in Southeast Asia, edited by Aihwa Ong and Michael Peletz, 19-50. Berkeley: University of California Press.

Bruijn, Mirjam de, and Rijk van Dijk. 2009. 'Questioning Social Security in the Study of Religion in Africa: The Ambiguous Meaning of the Gift in African Pentecostalism and Islam.' In Social Security in Religious Networks: Anthropological Perspectives on New Risks and Ambivalences, edited by Carolin Leutloff-Grandits, Anja Peleikis, and Tatjana Thelen, 105-127. New York: Berghahn Books.

Cheria Holiday. 2018. 'Napak Tilas di Bumi Para Nabi.' https://www.cheria-travel. com/2018/01/napak-tilas-di-bumi-para-nabi-11d9n.html.

Cohen, Erik. 1972. 'Toward a Sociology of International Tourism.' Social Research 39 (1): 164-182.

Feener, Michael. 2004. Islam in World Cultures: Comparative Perspectives. Religion in Contemporary Cultures. Santa Barbara, CA: ABC-CLIO.

Feldman, Jackie. 2015. 'Vehicles of Values: Souvenirs and the Moralities of Exchange in Christian Holy Land Pilgrimage.' In Toward an Anthropology of Nation Building and Unbuilding in Israel, edited by Fran Markowitz, 259-273. Lincoln: University of Nebraska Press.

Gordon, Beverly. 1986. 'The Souvenir: Messenger of the Extraordinary.' The Journal of Popular Culture 20 (3): 135-146. 
Hitchcock, Michael. 2000. 'Introduction.' In Souvenirs: The Material Culture of Tourism, edited by Michael Hitchcock and Ken Teague, 1-17. Aldershot: Ashgate.

Hoon, Chang-Yau. 2018. 'Pentecostal Megachurches in Jakarta: Class, Local and Global Dynamics.' In Pentecostal Megachurches in Southeast Asia: Negotiating Class, Consumption and the Nation, edited by Terence Chong, 21-46. Singapore: ISEAS-Yusof Ishak Institute.

Hospes, Otto. 1992. People that Count. Changing Savings and Credit Practices in Ambon, Indonesia. Amsterdam: Thesis Publishers.

Indonesian Ministry of Religious Affairs (Kementerian Agama Republik Indonesia). 2016. 'Waiting List.' https://haji.kemenag.go.id/v3/basisdata/waiting-list.

- 2013. 'Laporan Evaluasi Penyelenggaraaan Ibadah Haji Tahun 1434H/ 2013M.' https://haji.kemenag.go.id/v3/node/955363.

Indopos. 2018. '2019, Jamaah Umrah Diprediksi Meningkat.' December 19, 2018. https://indopos.co.id/read/2018/12/19/159346/2019-jamaah-umrah-diprediksimeningkat/.

Israeli Central Bureau of Statistics 2014, 2015, 2016. Tourist Arrivals. https://old. cbs.gov.il/reader/cw_usr_view_SHTML?ID=432. Accessed May 29, 2019.

The Jakarta Post. 2017. 'Indonesians Love of Mecca Boosts Lucrative "Umrah" Business.' February 21, 2017. https://www.thejakartapost.com/news/2017/01/21/ indonesians-love-of-mecca-boosts-lucrative-umrah-business.html.

The Jerusalem Post. 2011. 'Cabinet Quashes Plan to Rehabilitate Dead Sea.' November 20, 2011. https://www.jpost.com/Enviro-Tech/Cabinet-quashes-plan-torehabilitate-Dead-Sea.

Lücking, Mirjam. 2019. 'Travelling with the Idea of Taking Sides. Indonesian Pilgrimages to Jerusalem.' Bijdragen tot de Taal-, Land-en Volkenkunde 175 (2): $196-224$.

- 2017. 'Working in Mecca. How Informal Pilgrimage-Migration from Madura, Indonesia, to Saudi Arabia Challenges State Sovereignty.' European Journal of East Asian Studies 16 (2): 248-274.

2014. 'Making “Arab” One's Own: Muslim Pilgrimage Experiences in Central Java, Indonesia.' Internationales Asienforum. International Quarterly for Asian Studies 45 (1-2): 129-152.

Miller, Daniel. 1998. A Theory of Shopping. Cambridge: Polity Press.

Quinn, George. 2019. Bandit Saints of Java. Burrough on the Hill/Leicestershire: Monsoon.

- 2008. 'Throwing Money at the Holy Door: Commercial Aspects of Popular Pilgrimage in Java.' In Expressing Islam: Religious Life and Politics in Indonesia, edited by Greg Fealy and Sally White, 63-79. Singapore: Institute of Southeast Asian Studies.

Salaam Gateway. 2017. 'Indonesia's Different Mahram System Sends More Women than Men to Haj.' July 17, 2017. https://www.salaamgateway.com/en/ story/indonesias_different_mahram_system_sends_more_women_than_men_ to_haj-SALAAM17082017065744/.

Saudi Gazette. 2018. '1.2m Indonesians Coming for Haj, Umrah this Year.' June 11, 2018. http://saudigazette.com.sa/article/536789.

. 2017. 'A Million Indonesians to Perform Umrah this Season.' November 18, 2017. http://saudigazette.com.sa/article/522168/SAUDI-ARABIA/A-millionIndonesians-to-perform-Umrah-this-season. 


\section{Mirjam Lücking}

Schlehe, Judith. 2012. 'Moderne Paranormale als Spirituelle UnternehmerInnen in Indonesien?' ASIEN. Journal of Contemporary Asia (123): 95-111.

Slama, Martin. 2014. 'From Wali Songo to Wali Pitu: The Travelling of Islamic Saint Veneration to Bali.' In Between Harmony and Discrimination: Negotiating Religious Identities within Majority-Minority Relationships in Bali and Lombok, edited by Brigitta Hauser-Schäublin and David Harnish, 112-143. Leiden: Brill.

Syarifah, Umaiyah. 2017. 'Motif Sosial Melakukan Ibadah Hajj pada Masyarakat Desa Umbulmartani di Kecamatan Ngemplak.' Universitas Islam Negri Sunan Kalijaga. http://digilib.uin-suka.ac.id/3642/1/BAB\%20I, V.pdf.

Thimm, Viola. 2018. 'Embodying and Consuming Modernity on Muslim Pilgrimage: Gendered Shopping and Clothing Practices by Malaysian Women on "umrah and ziarah Dubai".' Asian Anthropology 17 (3): 185-203.

The Times of Israel. 2019. '2018 Saw Record Number of Tourists Visit Israel from Muslim Countries.' 6 May, 2019. https://www.timesofisrael.com/2018saw-record-number-of-tourists-visit-israel-from-muslim-countries/.

Wolf, Diane. 1990. 'Daughters, Decisions and Domination: An Empirical and Conceptual Critique of Household Strategies.' Development and Change 21 (1): 43-74.

Yulianto, Vissia Ita. 2007. Pesona 'Barat': Analisa Kritis-Historis tentang Kesadaran Warna Kulit di Indonesia. Yogyakarta: Jalasutra. 